\title{
Review of the Researches Progress on Managerial Power Theory
}

\author{
Qingguo Zhao ${ }^{1, \text { a }}$, Longqian Yang ${ }^{2, b}$ \\ ${ }^{1}$ Shenyang Aerospace University, China \\ ${ }^{2}$ Shenyang Aerospace University, China \\ azhqg1000@163.com, byang6225@126.com
}

Keywords: Research review, Managerial power theory, Agency theory

\begin{abstract}
This paper reviews the evolution and development of managerial power theory, and reviews related literature such as the measurement of power of management, the relationship between managerial power theory and compensation, performance and executive incentive. And then based on this, it makes analysis and summary, puts forward the future prospects.
\end{abstract}

\section{Introduction}

Management, as the name implies, refers to the person or organization responsible for the operation and management of a system, organization or unit. From an economic point of view, management is the place where the company, enterprise or organization is under management and the organization or personnel with management responsibility are responsible for the organization of daily production and operation activities and the formulation of its development strategy within the power framework, the most central figure of which is CEO. Management power, on the other hand, refers to the management's ability to organize production and business activities in accordance with its own thinking, that is, the company's regulatory oversight is insufficient, and its management shows its influence beyond its specific control right.

\section{Theory basis of managerial power}

\subsection{Commission theory of agency}

In 1976, Jensen and Meckling first proposed the principal-agent theory in "Theories of Vendors: Management Behavior, Agency Costs and Ownership Structure." [1] Then, Holmstrom (1979) and others further improved the principal-agent theory. Principal-agent theory holds that shareholders, as owners of the company, have divisions with the managers who are the managers of the company in the ultimate goal and interest. The early model of the enterprise is the combination of ownership and management rights. The owner of the enterprise also serves as the manager. Therefore, there is no conflict of interest. The enterprise manager will try their best to maximize their own profits and maximize the profit of individuals and enterprises Is synchronous. Under such circumstances, the profitability of enterprises, their own risk, managers naturally do not need supervision and incentives will be able to maximize their operating management talent. However, the development of production leads to the deepening of social division of labor. Capital owners are constrained by their energy and ability to turn their management rights over to professionals with the professional ability, time and energy to give them the power to manage the company. Thus, the ownership and management rights Unification has been separated, the modern enterprise system has been spawned, and the relationship between the commission and the agency came into being. However, with the separation of ownership rights and management rights, the problems and contradictions also arise accordingly. According to 18th century British classical economist Adam. Smith's "economic man" hypothesis, selfishness of human nature, are based on the maximization of their own interests as a guide to action, the client to pursue the maximization of corporate value, the agent is more emphasis on their own return and development, the existence of both natural Conflicts of interest. Agents using the convenience of their positions and managerial power to expand their on-the-job 
consumption, to extend their leisure time, or to expand their performance through over-investment, tend to undermine enterprise value and generate agency costs.

\subsection{The theory of asymmetric information}

In the course of business operation, due to the limitation of ability endowment and professional division of labor, the owner cannot be responsible for the business of the enterprise, which results in the operator having absolute superiority in information. If the principal cannot effectively identify whether the agent is competent, the agent may for his own benefit by concealing or providing false information to facilitate the contract, "adverse selection" arises. "Moral hazard" refers to the risk caused by the agent being lazy while the principal is under supervision. These problems will ultimately damage the value of the company and the shareholders' interests. The principal-agent theory explains the relationship between owners and managers, shareholders and management in modern enterprises. In order to minimize agency costs and promote the realization of enterprise value maximization, management power theory came into being.

\section{Research Status of Managerial Power Theory}

\subsection{Measurement of Managerial power}

Hambrick and Finkelstein (1987) think management power is reflected in the influence of business managers on decision-making and strategy [2]. Power has been identified as an abstract term that cannot be measured in detail. The appearance of the theory of management power broke the state and laid the foundation for the study of power. Finkelstein (1992) pioneered the general manager's power is divided into four dimensions, namely, structural power, expert power, prestige power and ownership power, which has far-reaching impact on the follow-up study [3]. He used the general manager of the board of directors and whether the number of concurrent pay to measure the structure of power; to general manager, the family ownership ratio and whether the founder of the company to measure the ownership of power; with the general manager of other units in the work and the industry in which they work The number represents the power of experts; the power of prestige is measured by the general manager's educational background and the number of directors of other companies. In the follow-up study, scholars considered more about the general manager's tenure, the general manager's and the chairman's concurrent positions, and the degree of ownership dispersion (Hu and Kumar, 2004; Combs and Ketchen, et al., 2007) Involved [4]. There are relatively few studies on management power in China, and the index system is greatly influenced by foreign countries. For example, R. Lu and M.H. Wei et al. (2008) adopted the three standards of two-part-time shareholding, shareholding decentralization and senior management term to measure management's power [5]. X.F. Quan and S.N. Wu et al. (2010) relied on the background of China's enterprise system and pioneered the use of the depth of the control chain of the pyramid of state-owned enterprises to enrich the power indicators of state-owned management [6]. In a nutshell, the management power measurement is divided into internal power and external power. The internal power has prestige and part-time job. The external power is mainly reflected in the corporate governance such as the decentralization of shares.

\subsection{Managerial power theory}

Research Management power research, overview at home and abroad, mainly in a few perspectives:

Managerial Power and Remuneration - Performance Sensitivity. R. Lu and M.H. Wei (2007) argue that the theory of management power is an important variable that explains pay and its structure, compensation and performance sensitivity. Many empirical studies have also proved this point. R. Lu (2008) found that the relationship between management power, salary and company performance, management power and monetary compensation are found to be positive, and pay gap will increase with the growth of on-the-job consumption, but the result does not support management. There is a positive correlation between power and performance. Empirical evidence 
also proved that the performance of a company is significantly and positively related to executive compensation. Moreover, the higher the power of the executive and the higher the remuneration, the lower the sensitivity of remuneration performance.

Managerial power and incentives. Management power and motivation are also the hot topics in the field of management power theory. There are two types of motivation: explicit and implicit motivation. Dominant incentives include remuneration and equity incentives, etc. Recessive incentives mainly involve on-the-job consumption and promotion. It is clear that executive pay will decrease as the supervisory board strengthens (Chhaochharia and Grinstein, 2009) [7]; executive pay will be more closely monitored if the company has external majority shareholders (Shleifer and Vishny, 1986); and Hartzell and Starks (2002) examines the sample company's remuneration and found that with the concentration of institutional investor ownership, board and executive authority is more closely monitored and executive pay is reduced. X, F, Quan and S.N. Wu et al. (2010) conducted a study of Chinese state-owned enterprises and also confirmed that the privately-owned earnings of senior executives will grow with the growth of management power [6].

Managerial power and information manipulation. Existing research suggests that executives may seek personal gain through the control of information. Guidry and Leone et al. (1999) argue that managers often overemphasize short-term values in order to obtain incentive compensation to maximize their bonuses, which often leads to a loss of long-term value to the company. Studies by Bergstresser and Philippon (2006) also confirm managers' use of informational convenience for personal gain and find that executives are likely to manipulate surpluses in order to obtain equity-related returns if stock prices are exaggerated and motivated by incentive pay Salary reward.

\section{Conclusion and inspiration}

Reviewing the literature both at home and abroad, we can find that the current research on management power focuses on executive compensation, incentives and private benefits, but not enough for the deeper research purpose, that is, the impact on corporate performance. In addition, management the measure of power is still rich in space, the future can be further studied.

\section{References}

[1] Jensen M.C, Meckling W.H. Theory of the Firm: Managerial Behavior, Agency Costs and Ownership Structure [M]. Springer Netherlands, 1976: 305-360.

[2] Hambrick D.C, Finkelstein S. Managerial Discretion: A Bridge between Polar Views of Organizational Outcomes. [J]. Research in Organizational Behavior, 1987, 9(4):369-406.

[3] Finkelstein S. Power in Top Management Teams: Dimensions, Measurement, and Validation. [J]. Academy of Management Journal Academy of Management, 1992, 35(3):505.

[4] Combs J.G and Ketchen D.J, et al. The Moderating Effect of CEO Power on the Board Composition-Firm Performance Relationship. Blackwell Publishing Ltd, 2007.

[5] R. LU, M. H. WEI. Progress in the Management of Power Theory [J]. Economic Management, 2008, (1): 90-93. (In Chinese)

[6] X.F. Quan, S.N. Wu and F. We. Management Power, Private Benefits and Compensation Manipulation [J]. Economic Research, 2010 (11): 73-87. (In Chinese)

[7] Chhaochharia V and Grinstein Y. CEO Compensation and Board Structure. The Journal of Finance. 2009. 